\title{
ACRL awards for 2001
}

\section{Celebrating the best in academic librarianship}

by Meredith Parets

S ince 1923, ACRL has been dedicared to recognizing and honoring the achievements of outstanding academic and research librarians. With the addition of three new awards in 1999, the ACRL Awards Program has grown to include 18 awards, including grants, fellowships, publication, and achievement awards. With the generous support of corporate sponsors, ACRL awards nearly $\$ 30,000$ each year to the best and brightest in academic librarianship.

\section{Take time to nominate a deserving colleague}

The prestige of the Awards Program ultimately rests upon the ACRL membership. We urge you to take some time to reflect on the accomplishments of your colleagues and to consider making nominations for the 2001 awards.

Award winners in the areas of Distinguished Service and Publication are selected by juries comprised of ACRL members, who rely on their peers to nominate outstanding librarians for consideration. Researchers and doctoral students are encouraged to submit proposals for one of the three fellowships and grants ACRL offers.

The enthusiasm and support of members ensures a distinguished and competi- tive pool of nominees and applicants, and the recognition that winners and nominees receive is especially meaningful because it comes from colleagues.

The ACRL office is happy to provide you with informational flyers for each award, which list submission procedures, award amount, criteria, and contact information. These flyers are also on the ACRL Web site at http://www.ala.org/ acrl.award2.html. Most awards have a December 1, 2000, deadline. Brief descriptions of each award are listed below.

\section{Achievement and distinguished service awards}

- Excellence in Academic Libraries Award (sponsored by Blackwell's Book Services): $\$ 3,000$ cash award for each of three awards (one in each type of library) that recognizes academic libraries that are outstanding in furthering the educational missions of their institutions.

- Academic or Research Librarian of the Year Award (sponsored by Yankee Book Peddler): $\$ 3,000$ cash award that recognizes an outstanding member of the academic or research library profession.

- Hugh C. Atkinson Memorial Award (sponsored by ACRL, ALCTS, LAMA, LITA): $\$ 2,000$ cash award that recognizes outstanding achievements (inclucling risk-tak-

\section{About the author}


ing) in the areas of library automation, management, or development and research.

- Marta Lange/CQ Award (sponsored by Congressional Quarterly, Inc.): $\$ 1,000$ cash award that recognizes a librarian who has made distinguished contributions to bibliography and information service in law or political science.

- Miriam Dudley Instruction Librarian Award (sponsored by Elsevier Science, Ltd.): $\$ 1,000$ cash award that recognizes an individual librarian for significant contributions to the adivancement of instruction in a college or research library environment.

\section{- Instruction Section Innovation in In-} struction Award (sponsored by Congressional Information Service): $\$ 3,000$ cash award for librarians who have implemented innovative approaches to information literacy at their respective institutions or in their communities.

\section{- Community Col-} lege Learning Resources Leadership/ Library Achievement Awards (sponsored by EBSCO Subscription Services): $\$ 500$ cash for each of two awards recognizing outstanding achievement in $\mathrm{l} i$ brary programs or leadership.

- Distinguished Education and Behavioral Sciences Librarian Award: Citation honoring outstanding contributions to education and behavioral sciences librarianship through accomplishments and service to the profession.

- Women's Studies Section Awards for Achievement (sponsored by Greenwood Publishing Group, Inc., Routledge): $\$ 1,000$ cash for each of two awards recognizing career or significant achievements in the area of women's studies librarianship.

\section{Research awards/grants}

- Doctoral Dissertation Fellowship (sponsored by Institute for Scientific Infor- mation): $\$ 1,500$ cash to assist doctoral students in the field with their dissertation research.

- Samuel Lazerow Fellowship (sponsored by Institute for Scientific Information): $\$ 1,000$ cash for travel and writing in the fields of acquisition or technical services.

- Martinus Nijhoff West European Specialist Study Grant (sponsored by Martinus Nijhoff, International): supports research pertaining to Western European studies, librarianship, or the book trade.

\section{Publications}

- Katherine Kyes Leab and Daniel J. Leab Exhibition Catalogue Awards (sponsored by Katherine Kyes Leab and Daniel J. Leab, American Book Prices Current): recognizes outstanding catalogs published by American or Canadian institutions in conjunction with library exhibitions.

- K. G. Saur Award for Best Article in College $\&$ Research Libraries (sponsored by $R . R$. Bouker/K. G. Saur): $\$ 500$ cash award for the most outstanding article published in $C E R L$ during the preceding volume year.

- Instruction Section Publication of the Year Award: recognizes an outstanding publication related to instruction in a library environment published in the last two years.

\section{Visit the Web for details}

For more information about the ACRL 2001 Awards Program, please visit our Web page at http://www.ala.org/acrl/ award2.html or contact Meredith Parets at (800) 545-2433

We look forward to receiving your nominations and celebrating your achievements in 2001. 